\title{
Retrospective Analysis of the Prevalence of Teeth Endodontically Treated from Radiographs of Individuals from the Midwest Region of Brazil
}

\section{Análise Retrospectiva da Prevalência de Dentes Tratados Endodônticamente a Partir de Radiografia de Indivíduos da Região do Centro Oeste no Brasil}

\author{
Lorena Alves Souza ${ }^{\mathrm{a}}$; Andrei Rosa*a; Lucas Barros Bonfim ${ }^{\mathrm{b}}$; Natália Garcia Santaella ${ }^{\mathrm{a}}$; Ivan Onone Gialainª Mateus \\ Rodrigues Tonetto ; Ricardo Danil Guiraldo ${ }^{\mathrm{a}, \mathrm{b}}$
}

\author{
a'Universidade de Cuiabá, Stricto Sensu Post Graduate Program in Integrated Dental Sciences. MT, Brazil. \\ bUniversidade de Cuiabá, Course of Dentistry. MT, Brazil. \\ 'Unopar, Stricto Sensu Post Graduate Program in Dentistry. PR, Brasil. \\ *E-mail: andrei5x@hotmail.com
}

\begin{abstract}
Endodontic treatment is common in dentistry and for a correct diagnosis it is necessary to observe clinical and radiographic signs, taking into account pulp and periapical changes in the element to be treated. Studying this frequency can contribute to the literature, elucidating whether the greatest number of cases is occurring in young or elderly patients, women or men, anterior or posterior teeth. The objective of this study was to analyze the prevalence of endodontically treated teeth, through 900 panoramic radiographs. A cross-sectional study was carried out evaluating the prevalence of teeth treated endodontically from a sample of 900 panoramic radiographs, corresponding to exams performed in 2020 , in a radiological clinic located in central west Brazil. The sample consisted of $540(60 \%)$ female subjects and 360 (40\%) male subjects, aged between 18 and 88 years old, being more prevalent for Individuals $<31$ years old with $(34.9 \%)$ Sample. The prevalence of endodontically treated teeth was analyzed, the results showed 1,236 teeth in this condition, individually analyzing the upper right central incisor was the most frequent $9.22 \%$, while for group analysis the upper teeth were $7.06 \%$. Therefore, there was a higher prevalence of teeth treated endodontically in the maxilla, the tooth with the highest treatment index, the right upper central incisor. Women were more affected and it was observed that with increasing age, the number of teeth treated endodontically also increases.
\end{abstract}

Keywords: Endodontics. Prevalence. Root Canal Obturation.

\section{Resumo}

O tratamento endodôntico é frequente na odontologia e para um correto diagnóstico é necessário observar sinais clínicos e radiográficos, levando em consideração as alterações pulpares e periapicais no elemento à ser tratado. Estudar essa frequência pode colaborar com a literatura, elucidando se o maior número de casos está ocorrendo em pacientes jovens ou idosos,mulheres ou homens, dentes anteriores ou posteriores $O$ objetivo desse presente estudo foi analisar a prevalência de dentes tratados endodônticamente, por meio de 900 radiografias panorâmicas. Foi realizado um estudo transversal avaliando prevalência de dentes tratados endodônticamente a partir de uma amostra de 900 radiografias panorâmicas, correspondentes a exames realizados em 2020, em uma clínica radiológica situada no centro oeste do Brasil. A amostra foi constituída por 540 (60\%) Indivíduos do gênero feminino e 360 (40\%) do masculino, com idade entre 18 e 88 anos de idade, sendo mais prevalente para Indivíduos $<31$ anos de idade com (34,9\%) da amostra. Foi analisada a prevalência de dentes tratados endodônticamente, os resultados mostraram 1.236 dentes nesta condição, analisando individualmente o incisivo central superiores direito foi o mais frequente 9,22\%, enquanto para análise de dentes por grupos foram os dentes anteriores superiores 7,06\%. Portanto, houve uma maior prevalência de dentes tratados endodônticamente em maxila, o dente com maior índice de tratamento o incisivo central superior direito. Mulheres foram mais acometidas e observou-se que com o aumento da idade, aumenta-se também o número de dentes tratados endodônticamente.

Palavras-chave: Endodontia. Prevalência. Obturação do Canal Radicular.

\section{Introduction}

Endodontics aims at tooth preservation, control of pulp alterations, returning oral health to the individual. Inflammatory changes in pulp tissue may be caused by caries, primary or secondary infection, apical periodontitis, symptomatic/asymptomatic, periapical abscess with/ without sinus pathway, open cavity/ closed cavity, history of trauma or lesion ${ }^{1-3}$. The treatment success rate for these cases with endodontic technique is approximately $90 \%$, when endodontic treatment is performed correctly ${ }^{4}$.

Currently, the techniques used during endodontic treatment provide the patient more comfort and agility to treatment and the advancement of technology associated with new endodontics techniques increase the success rate in endodontics ${ }^{5,6}$. For the diagnosis of pulp and periapical diseases, they involve the following alterations: hyper-reactive pulpagia, symptomatic pulpitis, asymptomatic pulpitis, pulp necrosis, symptomatic apical periodontitis of traumatic or infectious lesions without sinus tract, periapical abscess with sinus tract ${ }^{2}$.

For the correct diagnosis of buccal problems, complementary exams are used ${ }^{1}$, and radiograph is the most common of the exams. Panoramic radiography is a frequently used exam ${ }^{7}$ because it provides a more comprehensive image and convenience for clinical evaluation ${ }^{8}$. The socioeconomic factors directly reflect on the oral health of these patients, due 
to difficulty in accessing the dental treatment. Even with all the health policies available in the public network and means of prevention performed in schools, the rate of teeth with endodontic treatment is still high, data that can be observed in radiographic documentations ${ }^{9}$. Describing the profile of patients with a higher number of endodontically treated teeth may allow new health policies and prevention to these patients.

According to studies shown, the frequency of endodontic treatment can be evaluated by following radiographic parameters. And this frequency may elucidate whether the highest number is occurring in young patients, adults, anterior or posterior teeth. A descriptive analysis regarding the prevalence of endodontically treated teeth can collaborate with the literature due to scarcity on this subject. Therefore, the objective of this study was to determine the prevalence of endodontically treated teeth by the panoramic radiographs analysis.

\section{Material and Methods}

The initial sample consisted of 900 panoramic radiographs that were obtained from a private radiology clinic in the city of Cuiabá, state of Mato Grosso (MT), Brazil. The radiographic device used to obtain the images was Kavo OC 200D. The individuals in the sample were selected based on convenience, and the sample of radiographic examinations was performed between January 2020 and February 2020.

Initially, the images were collected and analyzed by an experienced dental surgeon. For the analysis, two evaluators previously calibrated evaluated 450 panoramic each. Before the analyzes, an evaluation pilot was performed of 30 panoramic radiographs of the evaluators together as a means of calibration. The images were evaluated in the actual size using precision software (®MPR-ProRadis Viewer) resources. In case of uncertainty about some point of the evaluation, the image could be analyzed jointly by the two evaluators to obtain a parameter in consent and the possibility of a third evaluator for consensus.

Patients who had teeth in the maxilla and jaw were included in the study. Teeth present, endodontically treated and absent were evaluated.

Exclusion criteria were patients presenting pathological processes in maxilla or mandible that hinder the tooth visualization, quality tests that prevent accurate analysis, patients submitted to reconstructive surgery with splint or other materials that could hinder the analysis, orthognathic surgery or any other surgical procedure in the analyzed region of the teeth, both in crown region and root, that could hinder the analyzes. Patients with deciduous dentition were also excluded. Radiographic examinations of total edentulous patients were discarded.

The data were collected and the variables counted in a table in an Excel program for later statistical analysis.

\section{Results and Discussion}

900 panoramic radiographs were analyzed which made it possible to analyze the dental condition of these individuals. Out of a total of 28,800 teeth of the individuals included in the study, the third molars were excluded from the sample, leaving a total of 25,200 dental elements. From this sample, teeth with endodontic treatment were evaluated according to gender and age, where 1,236 were endodontically treated.

Of the 900 individuals, it was observed mean age of 38.65 years, being the youngest individual 18 years old and the oldest person 88 years old. The sample consisted of 540 female individuals $(60 \%)$ with a mean age of 38.92 and 360 male individuals ( $40 \%$ ) with a mean age of 38.26 years, these data are consistent with findings from the literature showing a higher prevalence for the female gender. It is possibly explained due to the greater care and interest with oral health by women ${ }^{10} 11$ because they are more easily able to accept and/or seek dental treatment, seeking esthetics, beauty, selfesteem and vanity.

Regarding the age group in this study, there was a smaller sample for the age group of individuals over 61 years $(8.9 \%)$ and a larger one for individuals $<31$ years $(34.9 \%)$, as shown in Table 1.

Table 1 - Frequency for the age groups of the sample

\begin{tabular}{|c|c|c|}
\hline Age Range & Attendance & \% \\
\hline$<31$ & 314 & 34.9 \\
\hline $31-40$ & 215 & 23.9 \\
\hline $41-50$ & 167 & 18.6 \\
\hline $51-60$ & 124 & 13.8 \\
\hline$>\mathbf{6 0}$ & $\mathbf{8 0}$ & $\mathbf{8 . 9}$ \\
\hline
\end{tabular}

Source: Research data.

The youngest individuals were 18 years and the oldest ones 88 years, the age group that presented the smallest sample for individuals older than 61 years $(8.9 \%)$ and the largest one for individuals $<31$ years $(34.9 \%$ ). In this study, it can be observed that patients younger than 40 years of age had fewer teeth with endodontic treatment than expected and individuals older than 40 years had more endodontically treated teeth. According to studies in the literature, the prevalence of endodontically treated teeth is related to age increase $e^{12-15}$. Possibly this relation of endodontic treatment with age advancement is a reflection of the difficulty to access oral health, especially older generations who have experienced limited dentistry in technology, techniques and prevention policies.

Panoramic radiography is commonly used in the clinical routine, since it allows an evaluation of the maxillary and middle third of the face, as a simple exam with low cost and low doses of radiation exposure ${ }^{16,17}$. Although it presents distortions, panoramic radiography is indicated for some cases, when it is intended to evaluate third molars, endodontically treated teeth and other buccal alterations, therefore the use of this complementary exam helps to a correct evaluation of the oral health of the individual ${ }^{17}$. The number of patients who 
do not have access to dental treatment is high, on the other hand public health policies, have facilitated the contact of the population with oral health, providing better quality of life for these individuals, especially those who need public health, several programs guide and encourage prevention, from brushing to awareness about the importance of oral health.

The total sample was a universe of 900 individuals, third molars were excluded from the sample, obtaining a number of 25200 dental elements. In this universe, a total of 1236 teeth $(4.9 \%)$ were observed with endodontic treatment. This variable was analyzed for the teeth individually, it can be observed that the upper right central incisor had the highest frequency in this analysis with $9.22 \%$ (Figure 1)

Figure 1 - Relative frequency (\%) of endodontically treated teeth individually excluding third molars

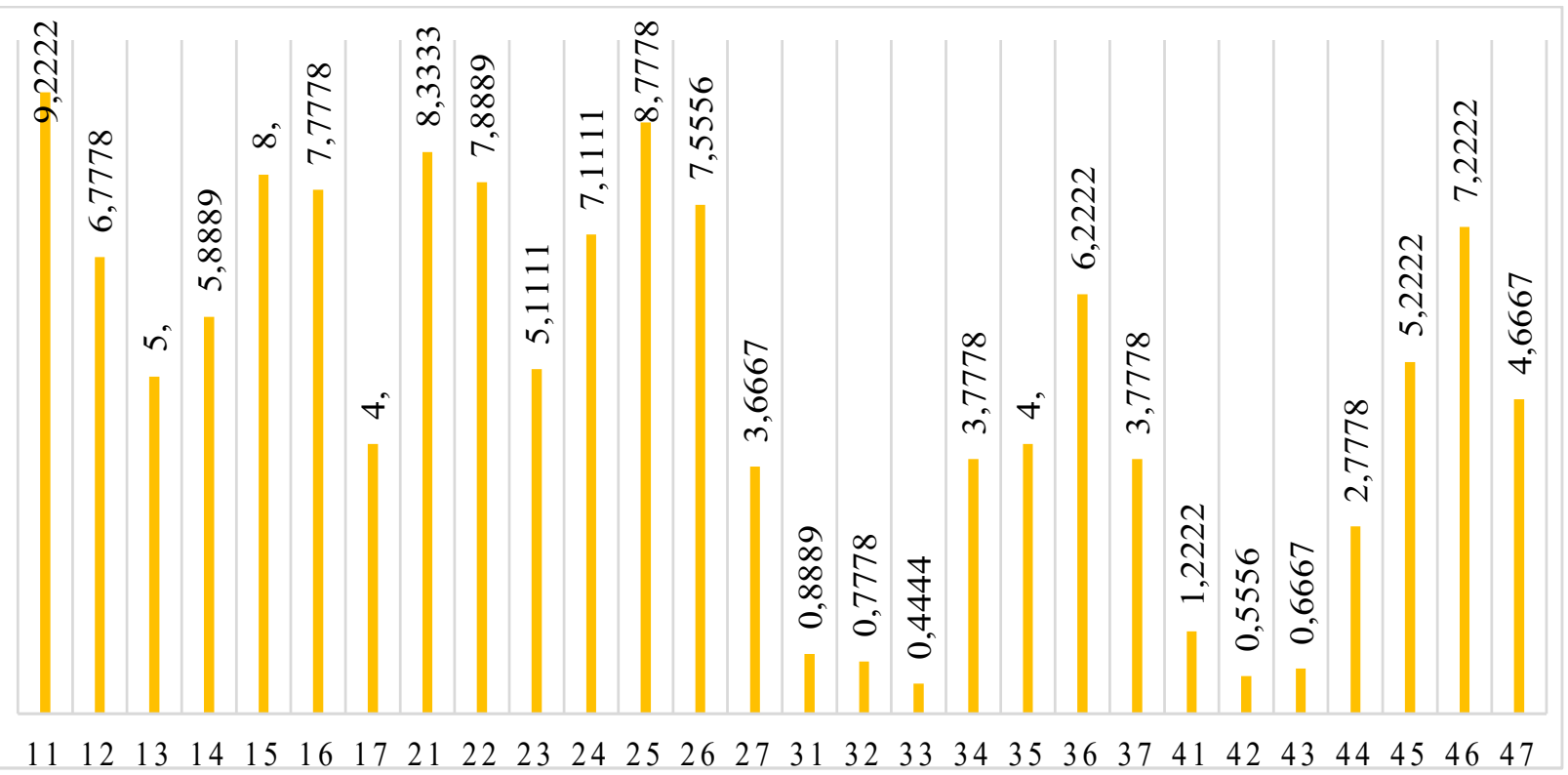

Source: Research data.

Upon observing these results, the most affected teeth were the upper right central incisors, totaling 9.22. The results for greater frequency in maxilla resemble others in the literature ${ }^{18,19}$, possibly the position in the dental arch facilitates traumas and other accidents, the age of rash in the oral environment generates greater exposure to extrinsic factors, as a diet rich in sucrose and among others, considering the difficulty of the individual in performing oral hygiene, increasing the chances of carious lesions and later need of endodontic treatment. Regarding the least affected teeth, it was possible to observe in this study that the lower canines had a lower frequency of endodontic treatment, totaling $0.44 \%$, where there is evidence in the literature that shows similar results ${ }^{20}$.

Endodontically treated teeth were divided into groups: upper anterior (upper central incisors, upper lateral incisors and upper canines), upper premolars (upper first and second premolars), upper molars (upper first and second molars), lower anterior (lower central incisors, lower lateral incisors and lower canines), lower premolars (lower first and second premolars), lower molars (first and second lower molars). After division into groups, the frequency of endodontic treatment was analyzed and it was observed that the group that showed the highest frequency was premolar upper with $7.44 \%$ (Figure 2).
Figure 2 - Relative frequency (\%) of endodontically treated teeth analyzed by dental groups

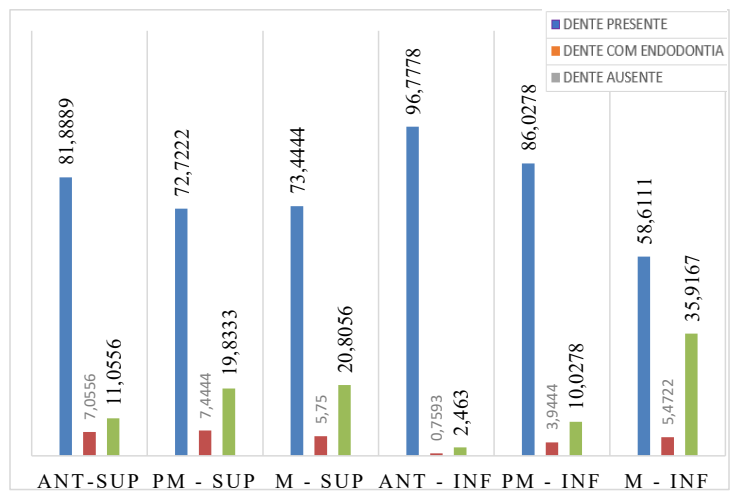

Source: Research data.

Regarding endodontically treated teeth, they were divided by gender and dental groups. The results found in this study (Figure 03) were more frequent for females, of a total of this variable of 1236 teeth, 861 were in females $(69.66 \%)$ and 375 in males $(30.34 \%)$. The most frequent group of teeth for the female gender were the upper anterior teeth (ANT-SUP) with 267 endodontically treated teeth, similarly this variable was shown in upper anterior teeth in the male gender with 114 endodontically treated teeth. The group of teeth with lower frequency were the lower anterior ones for females (29 teeth) 
and males (12 teeth).

Figure 3 - Absolute frequency of endodontically treated teeth analyzed by groups in the female and male gender

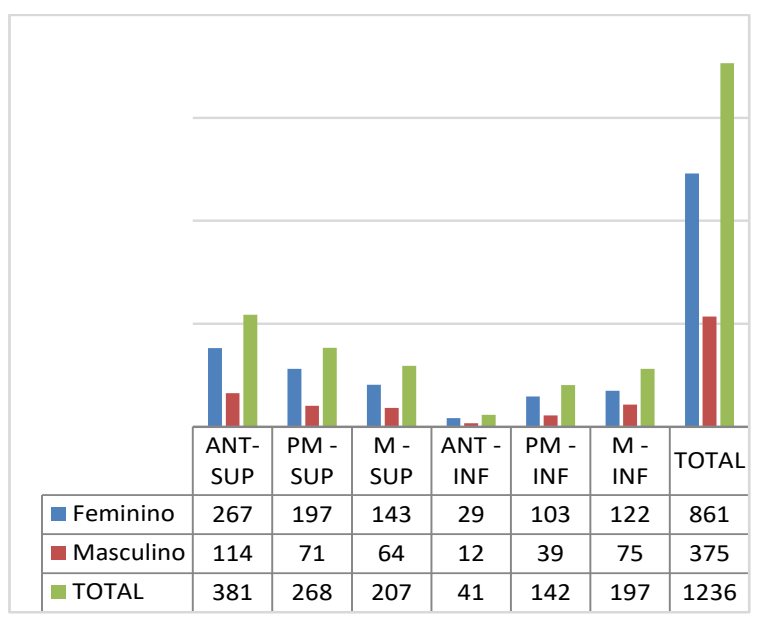

Source: Research data

Analyzing endodontically treated teeth by dental groups and age groups (Figure 4), it was observed that the upper central incisors were more frequent, after analyzing this group of teeth by age group, individuals between 51-60 years of age showed a higher frequency of endodontically treated teeth. Regarding the analysis of the absolute frequency of age group for all dental groups in this study in individuals $<30$ years were lower molars with 57 teeth, between 31-40 years anterior upper with 67 teeth, 41-50 years anterior upper with 100 teeth, 51-60 years anterior upper with 111 teeth and $>60$ years anterior upper with 67 teeth.

Figure 4 - Absolute frequency of endodontically treated teeth analyzed by groups regarding age

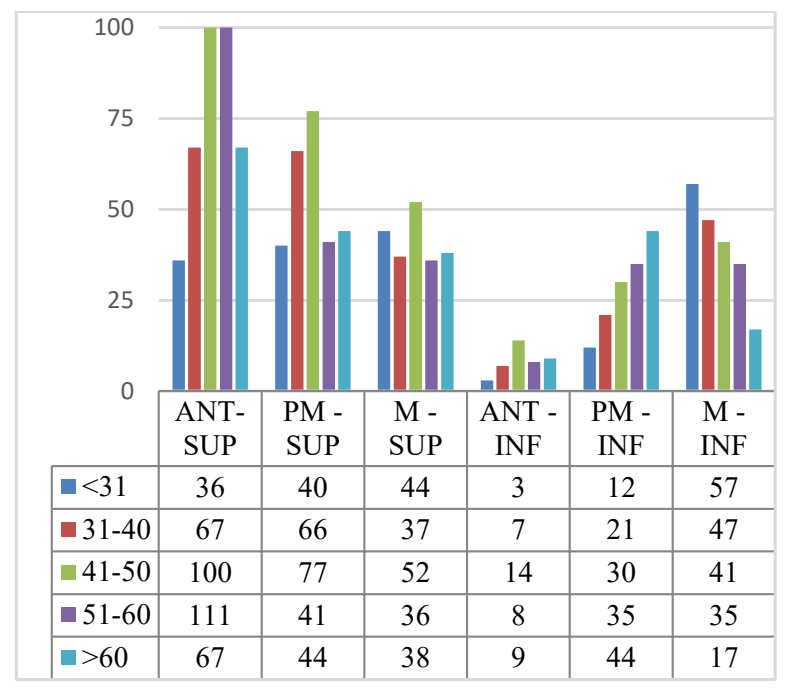

Source: Research data.

The data were analyzed by chi-square statistical test $(p<0.05)$ and statistical differences were found as shown in Table 2 .

Table 2 - Comparative analysis between gender for endodontically treated teeth

\begin{tabular}{|c|c|c|c|c|c|c|}
\hline & ANT-SUP & PM - SUP & M - SUP & ANT - INF & PM - INF & M - INF \\
\hline \multirow{2}{*}{ Female } & 267 & $197^{*}$ & $143^{*}$ & $29 *$ & $103^{*}$ & $122^{*}$ \\
\cline { 2 - 7 } & 228.6 & 160.8 & 124.2 & 24.6 & 85.2 & 118.2 \\
\hline \multirow{2}{*}{ Male } & 114 & 71 & 64 & 12 & 39 & 75 \\
\cline { 2 - 7 } & 152.4 & 107.2 & 82.8 & 16.4 & 56.8 & $<8.8$ \\
\hline \multirow{2}{*}{ chi-square } & $<0.000$ & $<0.000$ & $<0.013$ & $<0.012$ & $<0.007$ & $<0.000$ \\
\hline
\end{tabular}

Chi-square test $(\mathrm{p}<0.05)$. ${ }^{*}$ For statistical difference regarding gender.

Source: Research data.

According to the division of teeth into groups, a higher occurrence was observed in maxilla, being $7.06 \%$ in anterior upper, $7.44 \%$ in upper premolars and $5.75 \%$ in upper molars, while in lower anterior jaw, 6.76\% in lower premolars, $3.94 \%$ in lower premolars and $5.47 \%$ in lower molars, as shown in Table 3. These results can demonstrate a higher risk of endodontic treatment in maxilla. Regarding gender of a total of 1,236 endodontically treated teeth, 861 were in women $(69.66 \%)$ and 631 were in males $(30.34 \%)$, thus the data reinforce that women are more affected by endodontic treatment. The group of teeth with the highest number of endodontic treatments according to the female gender were the anterior upper, with 267 teeth treated, against 114 teeth endodontically treated in men.

\section{Conclusion}

Based in data found in this study, there was a higher prevalence of endodontically treated teen in maxilla, being the tooth with the highest index of treatment the upper right central incisor Regarding gender, women were more affected and it was observed that with age increase, there was an increase of endodontically treated teeth.

\section{References}

1. Estrela C, Holland R, Rodrigues C, Estrela DA. Characterization of successful root canal treatment. Braz Dental J 2014;25:3-11. doi: 10.1590/0103-6440201302356

2. Estrela C. Diagnostic and clinical factors associated with pulpal and periapical pain. Braz Dental J 2011;22:306-11. doi: 10.1590/S0103-64402011000400008

3. Estrela C, Silva JA, Decurcio DA, G AH. Monitoring nonsurgical and surgical root canal treatment of teeth with primary and secondary infections. Braz Dental J 2014;25:494501. doi: 10.1590/0103-6440201302437

4. Pereira LP, Traiano ML. Controle e avaliação dos tratamentos 
endodônticos realizados pelos acadêmicos do componente curricular de Endodontia II , em 2008 / 1 , do Curso de Odontologia da Universidade do Oeste de Santa Catarina. 2010;117-24. Unoesc Ciênc ACBS 2010;1(2):117-24.

5. Plotino G, Cortese T, Grande NM, Leonardi DP, Di Giorgio G, Testarelli L, et al. New technologies to improve root canal disinfection. Braz Dent J 2016;27(1):3-8. doi: https://doi. org/10.1590/0103-6440201600726

6. Campos CN. Campos AP, Bellei MC. Tecnologia a serviço da Endodontia : avanços no diagnóstico e tratamento de canais radiculares. Av Tencnol Odonto 2018;55-61. doi: https://doi. org/10.34019/1982-8047.2018.v44.13928

7. Leprincia A, Pontes B, Christiane F, Machado DA, Paula A, Costa S, et al. Avaliação da qualidade dos tratamentos endodônticos em Centros de Especialidades Odontológicas da Grande Natal- RN. Research Gate 2013;13(2):155-60 doi: 10.4034/PBOCI.2013.132.03

8. Sousa JL, Henriques A, da Silva ZP, Severo M, Silva S. Socioeconomic position and self-rated oral health in Brazil: Results of the brazilian national health survey. Cad Saude Publica 2019;35(6):1-13. doi: 10.1590/0102-311X00099518

9. Berlinck T, Tinoco JM, Carvalho FL, Sassone LM. Epidemiological evaluation of apical periodontitis prevalence in an urban Brazilian population. Braz Oral Res 2015;29(1):51. doi: 10.1590/1807-3107BOR-2015.vol29.0051

10. Boucher Y, Matossian L, Rilliard F, Machtou P. Radiographic evaluation of the prevalence and technical quality of root canal treatment in a French subpopulation. Int Endod J 2002;35(3):229-38. doi: 10.1046/j.1365-2591.2002.00469.x

11. Eriksen HM, Kirkevang L, Petersson K. Endodontic epidemiology and treatment outcome : general considerations. Entodontic Topics 2002. doi: https://doi.org/10.1034/j.16011546.2002.20101.x
12. Tsuneishi M, Yamamoto $\mathrm{T}$, Yamanaka R. Radiographic evaluation of periapical status and prevalence of endodontic treatment in an adult Japanese Population 2005;631-5.doi: 10.1016/j.tripleo.2005.07.029

13. Ahmed I, Ali RW, Mudawi AM. Prevalence of apical periodontitis and frequency of root-filled teeth in an adult Sudanese population. Clin Exp Dent Res 2017;3(4):142-7. doi: $10.1002 / \mathrm{cre} 2.73$

14. Al-Omari MA, Hazaa A, Haddad F. Frequency and distribution of root filled teeth and apical periodontitis in a Jordanian subpopulation. Oral Surgery, Oral Med Oral Pathol Oral Radiol Endodontol 2011;111(1):105-11. doi: 10.1016/j. tripleo.2010.08.007

15. Hidalgo Rivas A, Quintanilla Eymin P, Schilling Quezada A. Hallazgos en radiografías panorámicas de adultos mayores de Talca, Chile. Acta Odonto Venez 2013;51(2):11-2.

16. Santos KCP, Oliveira AS de, Hesse D, Buscatti MY, Oliveira JX de. Avaliação de radiografias panorâmicas objetivando o cotejamento entre os motivos da solicitação e eventuais achados radiográficos. J Heal Sci Inst 2007;25(4):419-22.

17. Camilo CC, Faria-e-silva AL. Prevalência e etiologia do retratamento endodôntico - estudo retrospectivo em clínica de graduação. RFO 2009;117-20. doi: 10.5335/rfo.v14i2.716

18. Pereira CV, Carvalho JC. Prevalência e eficácia dos tratamentos endodônticos realizados no Centro Universitário de Lavras, MG: uma análise etiológica e radiográfica. RFO 2008;13(3):36-41.

19. Araújo de Albuquerque L, Cynthia I, Archer E, Rafaella I, Silva de Souza M, et al. Prevalência de doenças pulpares e periapicais na Clínica de especializa- ção em Endodontia da FOP/UPE Rev Cir Traumatol Buco-Maxilo-Fac 2011;11(1). 